\title{
Recession and Educational Policy in Chile in the 1980s
}

\author{
Ruth Aedo-Richmond and Ines Noguera
}

The main focus of this article is the pattern of educational change in Chile from the early $1980 \mathrm{~s}$ onwards under the impact of structural adjustment and recession. Particular reference will be made to the Pinochet government's programmes of educational decentralisation and privatisation, policies which originally had been devised and introduced under relatively favourable economic conditions. In addition, particular attention will be directed towards the problems of Chilean youth insofar as their educational interests and needs have been damaged not only by the economic crisis but also by the military regime's response to the economic, social and political stresses affecting the country. Before embarking upon an analysis of these themes, it is important to recognise the character of the Pinochet regime and its policy orientations, as well as the antecedents of the economic difficulties associated with the recession and deep foreign indebtedness of the 1980 s.

\section{Political Background}

General Pinochet seized power in 1973 in a coup d'etat which brought to an end the democratically-elected socialist government of President Salvador Allende. The subsequent imposition of harsh military rule over all areas of state policy and national life turned Chile away from its democratic and constitutional traditions. A system of violent repression was institutionalised in order to crush the new regime's enemies inside Chile, and to demobilise a population whose expectations and political participation had been raised to unprecedented levels.

The political ideology of Pinochet's junta emerged gradually as an amalgam of several elements. The military regime's outlook manifested a deep authoritarianism allied with a fierce nationalism directed inwards towards all sources of domestic opposition. The junta saw its role as that of protecting, by whatever means, the spirit of 'Chilenidad' ('Chilean-hood') against the incursion of alien ideas and values; above all, Pinochet saw himself as the true defender of Western capitalist civilisation against the evils of Marxism and Communism. Traditional values such as the Christian religion, the family, private property, hierarchy, and individual freedom were constantly emphasised in 'the government's propaganda as bulwarks against the debilitating, corrupting influence of Marxist beliefs. The junta's attack on liberal practices and democratic pluralism partly rested on the view that communism was an insidious external force which had taken advantage of Chile's tradition of constitutional rule and 'open' politics. Declaring war on its ideological enemies, the regime committed itself to the Doctrine of National Security and avowed its intention of creating a new mentality which would reflect the key virtues of National Unity and 'Chilenidad' [Edholm 1982:33ff]. The main elements of the junta's ideology persist to this day. For Pinochet, the internal and external enemy continues to be Marxism, which is represented not only by its leftist adherents but also by those centrist and liberal forces which, by campaigning for a return to democracy and by opposing the continuation of his rule, wittingly or unwittingly help the communist cause.

A major stage in the evolution of the military regime occurred in 1980 when a new constitution proposed by Pinochet's government received popular approval in a national plebiscite. The 1980 constitution proved valuable to Pinochet in several ways, but especially as a legitimisation of the regime after seven years of extraconstitutional rule by presidential decree. In addition, the new constitution furnished a schedule for the subsequent development of the military regime and a highly circumscribed framework for the conduct of political activity and debate. Moreover, by appearing to return to constitutionality and by securing an undeniable measure of public support, the regime hoped to silence its foreign as well as its domestic critics. The 1980 constitution, however, merely institutionalised the kind of arbitrary exercise of power which Chile had experienced since 1973. At the time of writing, the constitutional programme for the transition to democratic rule has reached the point where a plebiscite on Pinochet's candidacy for an eight-year term of presidential office is imminent. It remains to be seen whether the promise of a domestic transition will be respected.

\section{The Economy after 1973}

Chile's economic system underwent a dramatic change during the years after the coup. However, it was not until 1975 that the alliance between the junta and a group of Chicago-trained economists was 
cemented properly. Before then, there had been some contradictory features of the new regime which had found expression in different approaches to Chile's economic problems. Thus, certain corporatist, fascist and conservative elements were drawn towards economic nationalism, protectionism, and a prominent economic role for the state. While these forces never disappeared entirely, by 1975 a team of self-confident, technocratic economists associated with Milton Friedman and his monetarist theory secured effective control over key ministries and began to implement their radical policies.

Faced with an externally-induced recession, a high and increasing inflation rate, a serious balance of payments crisis, mounting foreign debts, and an unstable currency, the new economic team introduced an Economic Recovery Programme which rejected a gradualist solution in favour of a form of economic 'shock treatment' [O'Brien and Roddick 1983:54-66]. Government spending was reduced by 27 per cent in 1975; capital investment declined by 50 per cent; the exchange rate was devalued; the government's privatisation programme was accelerated; import tariffs were slashed; and unemployment was allowed to rise rapidly. In addition, wage increases were held down and minimum wage rates were reduced.

The effect of these and other policy decisions was a massive deflation, whereby domestic demand was devastated and the level of imports fell considerably. Chile's GNP experienced a spectacular decline of about 12.8 per cent in 1975; industrial production was especially hard hit, falling by 28 per cent. Many bankruptcies occurred and several industries disappeared entirely. Unemployment rose officially to 19.8 per cent in early 1976 , but this figure could be placed more realistically at 28 per cent if Chileans working on the Programa de Empleo Mínimo (PEM: Minimum Employment Programme) were included. Unemployment rates in Santiago's shanty towns reached remarkable levels, in excess of 50 per cent in some cases. Middle sectors of the population were also affected adversely by the economic 'shock treatment' but generally they accepted the severe measures of economic restructuring and accompanying political repression as painful, short-term imperatives.

The Chicago-School economists proceeded to radically reorganise the Chilean economy. Their neo-liberal economic model contained a number of key feat ures: the economy would be 'open', that is, open to foreign capital and goods; unprofitable national industries would be allowed to decline if international comparative advantage dictated that this must happen; the notion of the 'subsidiary state' was to be realised in practice, partly through an extensive privatisation of state sector enterprises and partly through a broader withdrawal of the state from direct involvement in the economy; there was to be a reinvigoration of an export-oriented private sector and of free market mechanisms, including the development of the domestic capital market; and the labour market was to be "liberated' from the influence of powerful trade unions. This 'liberal' economic model, however, was intimately linked with a highly 'illiberal' and authoritarian system of military rule.

Following the economic crisis of 1975-76, an economic 'boom' occurred in Chile which, it was claimed, provided conclusive evidence of the correctness of the monetarist approach. A so-called 'economic miracle' appeared to be taking place on the basis of a systematic restructuring of the Chilean economy. The project of building a national industrial base, which had been the main economic objective of the country from the late 1930s onwards, had been abandoned. In its place, the Pinochet government pinned its hopes of economic revival and growth on balanced budgets, the conquest of inflation, and the expansion of the non-traditional exports sector. Eventually, after several peso devaluations, the exchange rate was fixed in 1979 at 39 pesos to the dollar:

The explicit rationale was that a fixed rate, with nearly all tariff protection removed, would force domestic firms to match competitive international prices. Inflation would then be driven down to the world level [Sheahan 1987:224].

Another feature of the 1977-81 'boom' period was the welcome given to multinational corporations, which were invited into Chile to enjoy the benefits of a lowwage economy and abundant investment opportunities. At the same time, there was a growing concentration of domestic economic power in fewer and fewer hands. Large conglomerate enterprises were formed, headed by individuals closely associated with the Chicagotrained economists in the government; these companies took particular advantage of the sell-off of state assets.

The economic 'boom', exemplified by impressive rates of economic growth (the average annual growth rate was 7.1 per cent between 1975 and 1981), increased consumer spending, and large injections of foreign capital, did not last, however. Alarming signs of impending trouble first began to appear in 1980; during the next three years, the economy suffered a major collapse, which was accompanied by an unravelling of the neo-liberal economic model. The economic crisis owed much to the extraordinary level of private sector indebtedness which had arisen. Vast amounts of foreign finance had flowed into Chile but little had found its way into solid, productive investment; instead, it had supported elaborate takeover campaigns, speculation in property and housing developments, and a remarkable bout of consumer spending which brought imports pouring into the country. Certain confidence-shattering bankruptcies 
occurred, revealing the fragile basis upon which the economic miracle had been built.

In 1982 , GDP fell catastrophically by 14.3 per cent. Industrial out put plummeted, falling from $11 \mathrm{l}$ in $198 \mathrm{l}$ to 94 in 1982 on an index of industrial production taking 1970 as 100 . The impact of the growing international recession was felt particularly strongly in Chile, owing to the government's policies and the way the economy had been allowed to develop during the 'boom' years. The peso, for example, had been overvalued by around 30 per cent. As a result, imports had been unusually cheap, while Chilean exports had begun to price themselves out of their foreign markets. These tendencies were exacerbated by rising real wages, which contributed to the rapid increase in unemployment from 198 I onwards (it was not until 1982 that a policy of wage indexation was abandoned). Open unemployment in Chile grew from 10 - 11 percent in 1981 to 19.2 per cent in 1982 . In greater Santiago, rates of open unemployment increased from 10.8 per cent in 1981 to 21.4 per cent in 1982 and 22.3 per cent in 1983; when data for PEM workers are added, the rates rise to $12.5,23.8$ and 27.6 per cent in these years. Eventually, the currency was devalued - by 18 per cent in June 1982 and by an additional 30 per cent in August of that year. Meanwhile, interest rates increased dramatically in 1981-82, plunging the economy further into its downward spiral. Though moderate by some Latin American standards, the inflation rate began to grow, from 9.5 per cent in $198 \mathrm{I}$ to 20.7 per cent in 1982 , reaching 25 per cent a year later.

As a consequence of Chile's economic collapse in the early 1980s, the Chicago School model blew up in Pinochet's face. As one crisis piled on top of another, rapid changes in government personnel ensued. Pinochet's faith in monetarism and its ideological advocates and practitioners was badly shaken, especially when the state was forced to intervene during the financial crisis by taking over a number of private banks and finance houses. Government restrictions on foreign exchange transactions also illustrated the irony of the situation: the adoption of the free market model had culminated in the expansion of the state's holdings and the reassertion of its powers of economic intervention.

\section{Social Costs after 1973}

Generally speaking, the social impact of the military regime and its policies has been to widen social divisions, to reduce the level of social participation, to deepen the poverty of urban and rural workers and their families, and to promote such values as individual competitiveness, consumerism, and personal success at the expense of solidarity and community. The coup and its immediate aftermath produced a kind of social trauma which left few families untouched. Killings, torture, disappearances, imprisonment, exile and sackings created high levels of individual and social distress. In addition, the application of monetarism and the free market model led to enormous social costs which the government did little to alleviate. In a revealing analysis, Scheetz has disputed the Pinochet government's repeated claims that it was devoting large and growing proportions of public sector spending to social programmes, even during the worst moments of financial crisis. According to Scheetz, "the long-term trend has been for defence outlays (and those of Police and Gendarmery) to increase, at the expense of social expenditures' [Scheetz 1987:1059]. In addition, he disaggregates Public Sector accounts in a way which shows which sub-sectors were cut back during the period of adjustment and stabilisation. Thus, as a percentage of public sector expenditures, education's proportion fell from 12.1 per cent in 1975 to 9.4 percent the following year; a similar pattern occurred in the early 1980 s, with education's proportion falling from 12.8 per cent in 1980 to 8.7 per cent in 1981 and 9.4 per cent in 1982 [Scheetz 1987:1058]. Accusing the Chilean authorities of performing a kind of 'accounting shell game', Scheetz provides clear evidence of the relative decline of education expenditures under military rule (relative, that is, to GDP and total Public Sector growth).

Scheetz's analysis corroborates other studies which challenge the military government's claims regarding social expenditures [see Foxley and Raczynski 1984]. Another sign of the Pinochet government's willingness to sacrifice education is provided by data on public investment. The 1974-82 period shows an overall pattern of decline in education's share of both total public investment and total public investment in the social sector: by 1982, in fact, education's share had fallen to 1.1 per cent of the former and 3.4 per cent of the latter, proportions rightly considered 'almost nonexistent' [Foxley and Raczynski 1984:227 and 229, Table V.5].

However, while there has been a general trend of reduction of social expenditures, some social programmes have been selected for special consideration, for example, schemes to provide nutritional help for young children (under six years of age) and pregnant women. The success of such highly targeted programmes, on the other hand, must be kept in perspective:

The social programmes after 1973 were highly selective. They were often carried out in a context of overall reduction of expenditure in the sector concerned. Some of these programmes were certainly not new, they constituted an extension, with some changes, of programmes that had been in operation in the country for many years. The 
changes were designed to make selective some programmes that had previously been allembracing and to enhance the benefits of the programmes in the case of high-risk or highly vulnerable groups [Foxley and Raczynski 1984:226].

Thus, after 1975, the Supplementary Feeding Programme ceased to cover children between 6 and 15 years of age. Moreover, the long-established programme of breakfasts and lunches for school children was sharply reduced under the military regime [Foxley and Raczynski 238-39]. In view of such considerations, one is well advised to be wary of Chilean government pronouncements regarding social expenditures, as well as of analyses which accept the official version uncritically.

\section{Educational Policy under Military Rule}

After the 1973 coup, the highest item on the junta's agenda for education was the need to establish immediate, direct military control over the whole educational system. This control was to be ideological as well as organisational: thus, many educational establishments were occupied by the military authorities; staff and students hostile to the new regime were purged, and curricula, books and study programmes were 'cleansed' in order to reflect the ideas and values of Pinochet's government. However, an overview of the $1973-78$ period reveals that the Chilean educational system was only partially modified and, despite certain obvious changes, the break with past practice and tradition was by no means complete. The state continued to exercise effective control over all facets of the educational process. Beginning in 1979, however, a series of educational changes was introduced which reflected the maturation of the regime's policies, especially regarding the long-term institutionalisation of military rule and the application of the free market economic model. The military government, and particularly Pinochet himself, felt the need to adapt the structure, functioning and content of education to the requirements of the kind of society which was being created.

On 5th March, 1979, a major restructuring of Chile's educational system was announced through the Directivas Presidenciales sobre Educación Nacional (Presidential Directives on National Education). In the following year, the new constitution introduced further changes in the pattern of educational provision. In addition, $1980-81$ also saw the promulgation of several decree laws and regulations designed to amplify and enforce the new educational reforms. The changes brought about by these enactments effectively broke the line of educational development stretching back to at least the 1920s. Pinochet's new policy contained a drastic revision and diminution of the state's role regarding the nation's education. Though not completely abdicating its educational responsibilities, Pinochet's government declared its intention to encourage private initiative in the provision of educational services. The state would guarantee eight years of primary schooling; however, according to Pinochet, secondary and higher education were to become. 'exceptional' and 'selective'.

In tune with the doctrine of the 'subsidiary state', the military government inaugurated a process of municipalisation, perhaps the most distinctive feature of the new educational policy. By no means confined to the educational system only, the municipalisation process envisioned the transfer of all state primary and secondary schools to the municipal authorities, that is, the Alcaldes or mayors. The central Ministry of Education was to retain its powers of technical supervision and control, but the municipalities were to assume direct responsibility for the administration of human and material resources. It is clear, however, that municipalisation was not regarded as an end in itself, but as a transitional stage on the road towards the goal of privatisation.

During the second half of the 1980 school year, 362 schools were transferred to the municipalities, along with 3,097 teachers and administrative staff and 67,208 pupils. By March 1981, 598 schools had been municipalised. In the Metropolitan Area of Santiago alone, 222 establishments (including 29 liceos or secondary schools) were transferred, along with 7,179 staff and 160,706 pupils, during the first semester of 1981. By April 1982, 84 per cent of state education in Chile had been transferred to the Alcaldes; this accounted for 5,724 establishments, 72,531 staff and about two million pupils [Núñez 1984:132].

It was at this point in early 1982 that the process of municipalisation was abruptly frozen in its tracks. Under the impact of the recession and resultant financial stringencies, the Pinochet government found itself unable to afford the completion of the transfer of state schools, teachers and pupils to the municipal authorities. Under Decree Law 3477 (September 1980), the government had promised to give extra financial assistance to those municipalities which undertook to accept the transfer of education and health services; in addition, it had announced its intention to award a kind of redundancy payment, based on years of service, to those teachers who agreed to be transferred. In 1982, the government discovered not only that it could no longer afford the extra assistance but also that it had to freeze the amount of educational subsidy available to municipal and private subsidised schools. As a result, these schools experienced difficulties in sustaining their levels of operation, especially in conditions of rising inflation; it may be assumed that a casualty of this situation was the quality of schooling. Moreover, the cost of the redundancy payments (or transfer inducements) 
available to state teachers proved to be prohibitive in the difficult financial circumstances facing the government. In the light of such considerations, Núñez has pointed out the contradiction between the government's explanation of its decision to halt the municipalisation process and its claims that public expenditures for social programmes (including education) had not been reduced [Núñez 1984:133]. It may be noted that it was not until 1986 that the policy of transferring state education to the municipalities was reactivated [Hevia 1986:243]; during that year, the municipalisation process was completed in the metropolitan area [Espínola 1987:6].

As stated earlier, the original conception of municipalisation was that it would serve as a transitory stage in the movement toward the privatisation of Chilean schooling. The latter has to be understood mainly in terms of the transfer of schools from the Alcaldes to privately-run establishments supported by state subsidies calculated on the basis of pupil attendance. During the economically difficult years of the early 1980s, a significant change occurred in the distribution of enrolments amongst different types of school in Chile. In 1981, 78.0 per cent of pupils were enrolled in state and municipal schools, 15.1 per cent in private subsidised schools, and 6.9 per cent in private fee-paying schools. By 1985 , the relative proportions had changed to $65.3,28.5$ and 6.1 per cent respectively. Most noticeable is the increased proportion of enrolments in private subsidised schools [Cox 1987:12]. However, impressive though this development has been, it should be recognised that the degree and pace of change were probably held back by the economic conditions prevailing in the country. As the economy recovers, it can be anticipated that a higher proportion of pupils will be enrolled in private subsidised schools in future. Another prospective development is the emergence of 'semi-subsidised' schools, financed partly by the state and partly by parents anxious to give their children a better education than that available in municipal or non-feepaying private schools [Hevia 1986:245].

These trends regarding municipalisation and privatisation have brought new patterns of inequality to Chilean schooling over and above those traceable directly to the economic recession. It is clear that the severe economic problems of the 1980s delayed the implementation of the Pinochet government's plans for educational reform but did not bring about a fundamental redirection of policy. Many criticisms have been levelled against the government's programmes of municipalisation and privatisation of education, but the military regime had defended and justified them on the grounds that they bring greater administrative efficiency, an improvement in the quality of education, more responsiveness to local circumstances and parental choice, and cost savings in educational provision. On the latter point, the Pinochet government has argued its case for privatisation by maintaining that private subsidised schooling offers significant cost advantages. According to official claims, the cost per pupil in state, municipal and private subsidised schools is $27,000,22,000$ and 20,000 pesos per annum respectively [Hevia 1986:245].

Critics, however, have argued that municipalisation and privatisation have many weaknesses and disadvantages in terms of both theory and practice. For example, the transfer of state schools to the municipalities between 1980 and 1982 was undertaken hastily and without the promised experimental stage which would have permitted a proper evaluation of the programme. Moreover, the massive transfer of public educational facilities was undertaken without prior public debate. Of particular concern to some critics was the fact that control over education had been transferred from the hands of educational authorities and was now directly exercised by the Alcalde, a political authority appointed by Pinochet, who usually had no experience of educational administration. Furthermore, worries have been expressed that municipalisation and privatisation would affect the quality of education adversely and would introduce a highly uneven pattern of provision in the country: the type, extent and quality of education, it was feared, would tend to reflect the class composition of the municipalities [Garcia Huidobro 1986:44].

One particular reason why quality would be at risk is because the basis of allocation of state subsidies would tend to encourage private schools to be more concerned with pupil numbers than with standards. In addition, private subsidised schools tend to offer teachers less security of employment, and typically pay teachers considerably less than do state and municipal schools [Gonzalez 1988:10]. According to one analysis, privatisation has produced new conditions of employment for teachers tantamount more often than not to exploitation' [Cox 1987: 1213]. Quality of education is also undermined by the limited amount of resources available in municipal and private subsidised schools, especially in lowincome communities.

\section{Youth, Education and Employment}

A number of recent studies have highlighted the problems facing Chilean youth in the 1980s. To understand these complex problems, it is important to bear in mind the social trends in preceding decades which had seen a marked improvement in the educational levels of young people across all social categories, as well as enhanced possibilities for social mobility in a modernising economy. This is not to deny the persistence of social inequalities affecting the educational and employment opportunities of young 
people, but it does recognise the boost given to education by the kind of modernisation strategy being pursued. The following data provide some indication of the educational expansion that was achieved. Between 1960 and 1980, attendance rates amongst young Chileans aged 15 years increased from 56.4 per cent to 84.2 per cent; for 18 year olds, the attendance rates were 22.7 per cent and 60.3 per cent in these years. During the same period, the proportion of young people (15-24) with less than three years of schooling fell from 31.7 per cent to just 5.6 per cent; meanwhile, those with ten years of schooling or more grew from 8.3 per cent to 41.4 per cent [Garcia Huidobro 1986:42]. In association with the expansion of education there occurred a decline in the rates of economic participation of young people (15-19) from 42.2 per cent in 1960 to 30.7 per cent in 1970; this reduction was most pronounced in urban areas (from 38.8 per cent to 27.2 per cent) and amongst males (from 61.7 per cent to 45.3 per cent) over this period [Martínez and Valenzuela 1986:93].

This educational expansion, however, was never properly matched by the growth of employment opportunities in the modern economic sectors which were expected to accommodate the better-educated workforce. This was one facet of the mounting difficulties facing the modernisation strategy based on import-substituting industrialisation. The unravelling of this strategy and the emergent crisis of structural economic readjustment have created new predicaments for Chilean youth. In particular, their elevated educational levels contrast sharply with the new patterns of employment in an economy which has experienced not only a contraction of manufacturing industry, construction, transport and commerce [Leiva and Petras 1986:10] but also a redefinition of the economic role of the state (including its role as an employer). In circumstances of structural change and economic recession, several pronounced tendencies affecting Chilean youth may be observed.

First, the overall proportion of students in the age group has grown, from 66.8 per cent to 71.7 per cent for $15-19$ year olds and from 18.7 per cent to 19.6 per cent for 20-24 year olds between 1980 and 1984. These increases reflect the inhospitable nature of the labour market in the early 1980s [Rama 1986:30]. Second, it is evident that there are clear differences in the ability of families from different social backgrounds to sustain their offspring in school, especially in the 20-24 agerange [Rama 1986:31]. Third, for those young people actively seeking employment, the types of occupations available to them have changed considerably in recent years, especially in relation to manual work. According to Rama:

In 1984 it is pract ically impossible for young people with only primary education to become manual workers; with such limited recru it ment and such an ample labour supply, it is necessary to have something more than basic education to become a manual worker [1986:34]

Fourth, a clear trend exists towards social exclusion of youth and related forms of occupational exclusion, both of which correlate strongly with social background and levels of education. Increasing numbers of young people, especially those from poor backgrounds and with lower educational levels, are being excluded from formal employment and are being socially marginalised through processes of unemployment, underemployment, and involvement in urban informal sector activities [see Martinez and Valenzuela 1986:96-101].

\section{Conclusion}

Clearly, the changed economic conditions of the $1980 \mathrm{~s}$ are serving to frustrate many well-educated young Chileans whose hopes of social mobility and occupational access have little chance of realisation. In these circumstances, the function of socio-cultural homogenisation formerly entrusted to an expansionary educational system has collapsed under the pressures exerted by strengthened processes of social stratification. As social class background comes increasingly to determine real educational and career opportunities through a segmented educational system, Chilean society seems set to become more and more polarised and divided.

\section{References}

Cox, C., 1987, The Structuring of Schooling: The Case of Chile, CIDE, Santiago

Edholm, F. (ed.), 1982, Education and Repression: Chile, World University Service, London

Espinola, V., 1987, Reformas Educativas del Regimen Militar y Calidad de la Educación, CIDE, Santiago

Foxley, A. and D. Raczynski, 1984, "Vulnerable groups in recessionary situations: the case of children and the young in Chile', World Development, vol 12 no 3, pp 223-46

Garcia Huidobro, J. E., 1986, 'Juventud Chilena: Educación y Empleo', Mensaje, no 346, pp 42-6

Gonzalez, C., 1988, 'Maestros a precio de liquidación', La Epoca, 15 May, pp 10-11

Hevia, R., 1986, 'El Dilema de los Transpasos: Alcaldización o Privatizacion', Mensaje, no 350, pp 243-5

Leiva, F. I. and Petras, J., 1986, 'Chile's Poor in the Struggle for Democracy', Latin American Perspectives, vol 13 no 4, pp 5-25

Martinez, J. and Valenzuela, E., 1986, 'Chilean youth and social exclusion', CEPAL Revien', no 29, pp 93-105 
Núñez, I., 1984, Las Transformaciones de la Educación bajo el Regimen Militar, PIIE, Santiago

O'Brien, P. and Roddick, J. 1983, Chile: The Pinochet Decade, Latin America Bureau, London

Rama, G. W., 1986, 'Latin American you th between development and crisis', CEPAL Review, no 29, pp 17-39
Scheetz, T., 1987, 'Public sector expenditures and financial crisis in Chile', World Development, vol 15 no 8, pp 1053-75

Sheahan, J., 1987, Patterns of Development in Latin America, Princeton University Press, Princeton (NJ) 